\title{
PENELAAHAN BUKU TEKS PELAJARAN KURIKULUM 2013 \\ DITINJAU DARI ASPEK KELAYAKAN ISI, PENYAJIAN, BAHASA, DAN KEGRAFIKAAN
}

\author{
Suratni, Jimmy Paat \\ Program Studi Penerbitan, Jurusan Penerbitan, \\ Politeknik Negeri Media Kreatif Jakarta \\ Surel: ratni@polimedia.ac.id
}

\begin{abstract}
The purpose of this research is to examine the results of the review of the Independent Reviewer Team. The researcher uses a qualitative descriptive method to describe valuations of the reviewer. Furthermore, she reduces the data and sets 18 textbooks for this research data (23,68\%). Overall, the aspectsof the feasibility of textbooks in Curriculum 2013 is divided into two categories, namely 'quite decent 'and 'worthy'. However, to make it a textbook in use nationally, aspects of the content, the presentation, the language, and the printing quality of the book have to be repaired, fitted, and maximized again.
\end{abstract}

Keywords: text books, curriculum feasibility, 2013, content, presentation, language, printing quality

\section{PENDAHULUAN}

Telah menjadi $\begin{array}{r}\text { kewajiban } \\ \text { sebagaimana }\end{array}$
pemerintah
diamanatkan dalam $\begin{array}{r}\text { Pembukaan } \\ \text { Undang-Undang Dasar Negara }\end{array}$ Republik Indonesia Tahun 1945 untuk mencerdaskan kehidupan bangsa dan memberi kesempatan yang sama memperoleh pendidikan bagi segenap rakyat Indonesia. Tujuan tersebut selanjutnya ditetapkan melalui program pendidikan wajib belajar (wajar) dasar 9 (sembilan) tahun sejak 2 Mei 1994. Undang-Undang No. 20 Tahun 2003 tentang Sistem Pendidikan Nasional (Sisdiknas) yang menyatakan bahwa pemerintah pusat dan daerah menjamin terselenggaranya wajib belajar minimal untuk jenjang pendidikan dasar tanpa memungut biaya merupakan bukti kesungguhan pemerintah untuk mencerdaskan anak bangsa. Undang-Undang Nomor Visual Artikata Penelaahan 19 Tahun 2005 tentang Badan Standar Nasional Pendidikan (BSNP) dibentuk dalam upaya untuk meningkatkan kualitas pendidikan secara menyeluruh.

Berbagai upaya peningkatan kualitas pendidikan tersebut membutuhkan dana yang cukup besar. Terkait dengan pendanaan, pemerintah telah menaikkan anggaran pendidikan hingga 20\% dari Anggaran Pendapatan Belanja Negara (APBN) sejak tahun 2009. 
Anggaran ini diharapkan dapat memenuhi kebutuhan di bidang pendidikan, salah satunya untuk penyediaan buku teks pelajaran dan buku-buku penunjang di sekolah. Perhatian pemerintah terhadap buku sekolah meliputi kualitas dan kuantitasnya.

Buku teks pelajaran menjadi faktor penting dan strategis dalam upaya meningkatkan mutu pendidikan dasar dan menengah. Oleh karena itu, perlu ada adanya perbaikan kualitas buku teks pelajaran secara terus menerus dalam rangka memberikan pelayanan pendidikan terbaik kepada rakyat Indonesia.

Dalam Peraturan Menteri Pendidikan Nasional (Permendiknas) Nomor 2 Tahun 2008 memuat kebijakan perbukuan yang meliputi hal ketentuan umum, penulisan buku, penilaian buku teks, pemilihan buku teks di satuan pendidikan, penggunaan buku di satuan pendidikan, penggandaan, penerbitan, distribusi buku, masa pakai buku teks pelajaran, pendanaan, pengawasan, dan sanksi. Salah satu cara yang ditempuh pemerintah untuk meningkatkan mutu pendidikan adalah dengan diberlakukannya kurikulum baru mulai tahun ajaran 2013/2014. Meskipun masih menuai pro-kontra, pemerintah resmi meluncurkan kurikulum 2013 untuk diimplementasikan pada sekolah dengan jumlah masih terbatas.

Berkaitan dengan proses penyiapan buku teks pelajaran kurikulum 2013, pelaksanaan manajemen penerbitan buku tersebut dilakukan oleh Pusat Perbukuan dan Kurikulum (Puskurbuk) bekerja sama dengan Politeknik Negeri Media Kreatif (Polimedia) yang memiliki kompetensi dan peralatan pendukung untuk melaksanakan proses manajamen penerbitan buku.

Sebelum diterbitkan, bukubuku tersebut telah ditelaah oleh Tim Penelaah Independen yang ditunjuk dengan Surat Keputusan Menteri Pendidikan dan Kebudayaan. Tim tersebut menelaah buku teks pelajaran dengan Standar Penilaian Buku Teks Pelajaran yang diatur dalam Peraturan Presiden Nomor 19 Tahun 2005 dan Permendiknas Nomor 2 Tahun 2008. Namun demikian, belum ada penelitian atau pun kajian terhadap hasil penilaian Tim Penelaah Independen tersebut.

Penelitian ini disampaikan atas dasar pengalaman para peneliti sebagai bagian dari Tim Polimedia sebagai wujud kontribusi evaluasi atas pelaksanaan manajemen penerbitan yang telah dilakukan oleh Kementerian Pendidikan dan Kebudayaan untuk menyediakan buku sekolah yang bermutu sesuai dengan kurikulum 2013 sehingga penelitian ini hendak mendeskripsikan hasil penelaahan terhadap buku teks pelajaran kurikulum 2013 ditinjau dari aspek kelayakan isi, penyajian, bahasa, dan kegrafikaan. 


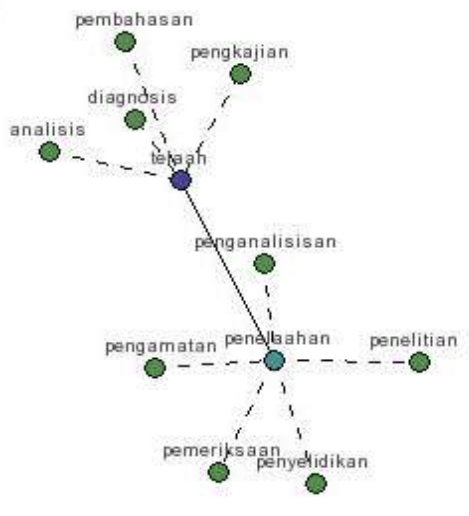

Gambar 1 Konsep kata penelaahan

Sumber: http://www.artikata.com/arti$\underline{\text { 380917-penelaahan.html }}$

Berdasarkan Gambar 1 tersebut kata 'penelaahan' berasal dari kata dasar 'telaah'. Kata 'penelaahan' ini merupakan kata benda yang memiliki arti: penyelidikan; kajian; pemeriksaan; penelitian: mereka mengadakan -- untuk permukiman;

me'ne'la·ah $\quad v \quad \mathbf{1}$ mempelajari; menyelidik; mengkaji; memeriksa; menilik: kita perlu buku-buku yg mutakhir; 2 meramalkan: ia minta agar dukun itu nasib dirinya;

pe·ne·la·ah $n$ orang yg menelaah; orang yg mengkaji, menyelidik; pemeriksa; peneliti;

$\mathbf{p e} \cdot \mathbf{n e} \cdot \mathbf{l a} \cdot \mathbf{a h} \cdot \mathbf{a n} n$ proses, cara, perbuatan menelaah.

Dalam hal ini, yang dimaksud dengan penelaahan adalah suatu proses di mana peneliti mempelajari, menyelidik, mengkaji, memeriksa, dan meneliti hal-hal yang terkait dengan hasil penilaian buku teks pelajaran yang dilakukan oleh penelaah yang ditunjuk dengan Surat Keputusan Menteri Pendidikan dan
Kebudayaan. Sedangkan, penelaah adalah orang yang ahli di bidangnya yang mengkaji buku teks pelajaran.

Kementerian Pendidikan dan Kebudayaan mengerahkan semua sumber daya untuk menyempurnakan kurikulum 2013. Dalam penyusunan buku siswa dan buku guru, Kemdikbud mengundang penelaah independen guna memastikan kelayakan buku tersebut untuk dipakai dalam proses pembelajaran. Menurut Menteri Pendidikan dan Kebudayaan (Mendikbud) Mohammad Nuh, "Baru kali ini kementerian menulis buku. Biasanya kan diserahkan ke penulis baru setelah selesai, diserahkan dan direview oleh Puskurbuk dan BSNP." Mendikbud menjelaskan, diundangnya penelaah independen dalam penyusunan buku kurikulum 2013, adalah untuk mencermati beberapa hal. Pertama, agar tidak terjadi salah konsep dalam buku yang dibuat. Kedua, kehadiran tim independen ini adalah untuk memastikan bahwa buku-buku ini tidak menimbulkan kontroversi. Terutama dari segi konten. Misalnya, di dalam bab tertentu penulis memasukkan gambar mantan Presiden Soekarno, dan Presiden SBY, tentu akan menjadi kontroversi jika tidak ada mantan Presiden Gus Dur, Megawati atau Habibie. Yang ketiga, untuk memastikan tidak ada kesalahan unsur cetak di buku yang sedang disiapkan ini. Buku-buku untuk kurikulum 2013 ditargetkan untuk didistribusikan tepat pada waktunya, yaitu bulan Juli 
mendatang sehingga di hari pertama masuk sekolah, para siswa telah memperoleh buku-buku tersebut imbuhnya.

Buku pelajaran (textbook) menurut beberapa ahli adalah media pembelajaran (instruksional) yang dominan peranannya di kelas; media penyampaian materi kurikulum; dan bagian sentral dalam suatu sistem pendidikan Secara lebih spesifik, Chambliss dan Calfee (1998) menjelaskan bahwa buku pelajaran adalah alat bantu siswa memahami dan belajar dari hal-hal yang dibaca. Buku pelajaran juga merupakan alat bantu memahami dunia (di luar dirinya). Buku pelajaran memiliki kekuatan yang luar biasa besar terhadap perubahan otak. Buku pelajaran dapat mengubah otak siswa. Kekuatan buku pelajaran yang mempengaruhi pengetahuan anak dan nilai adalah suatu asumsi agar buku pelajaran harus disusun secara bermutu.

Di dalam Permendiknas Nomor 11 Tahun 2005 dijelaskan bahwa buku teks pelajaran adalah buku acuan wajib untuk digunakan di sekolah yang memuat materi pembelajaran dalam rangka peningkatan keimanan dan ketakwaan, budi pekerti dan kepribadian, kemampuan penguasaan ilmu pengetahuan dan teknologi, kepekaan dan kemampuan estetis, potensi fisik dan kesehatan yang disusun berdasarkan standar nasional pendidikan.

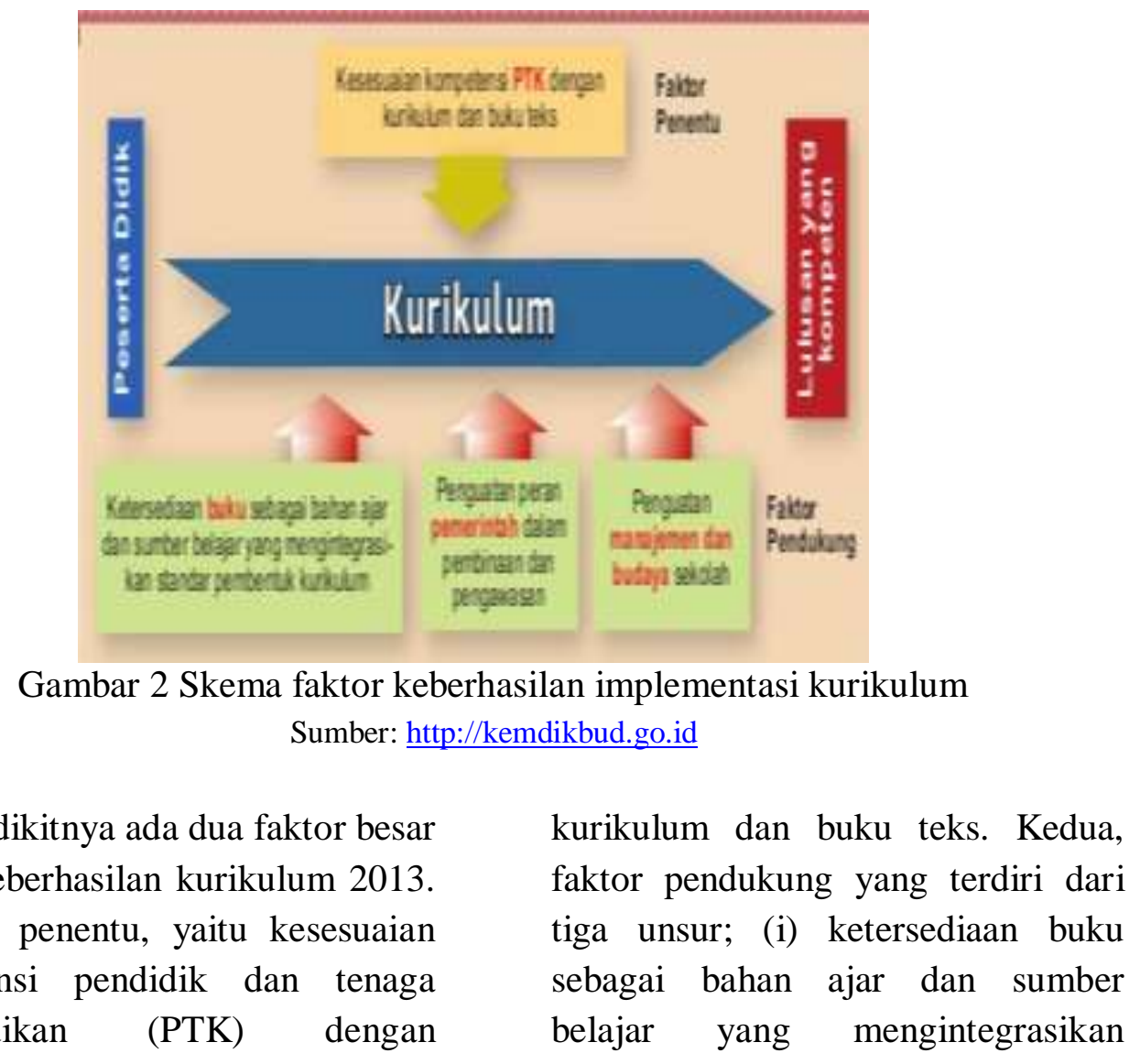


standar pembentuk kurikulum; (ii) penguatan peran pemerintah dalam pembinaan dan pengawasan; dan (iii) penguatan manajemen dan budaya sekolah.

Terkait dengan faktor pertama, Kemdikbud telah mendesain strategi penyiapan guru sebagaimana digambarkan pada Gambar 2 yang melibatkan tim pengembang kurikulum di tingkat pusat; instruktur diklat terdiri atas unsur dinas pendidikan, dosen, widyaswara, guru inti, pengawas, kepala sekolah; guru utama meliputi guru inti, pengawas, dan kepala sekolah; dan guru mereka terdiri atas guru kelas, guru mata pelajaran SD, SMP, SMA, SMK.

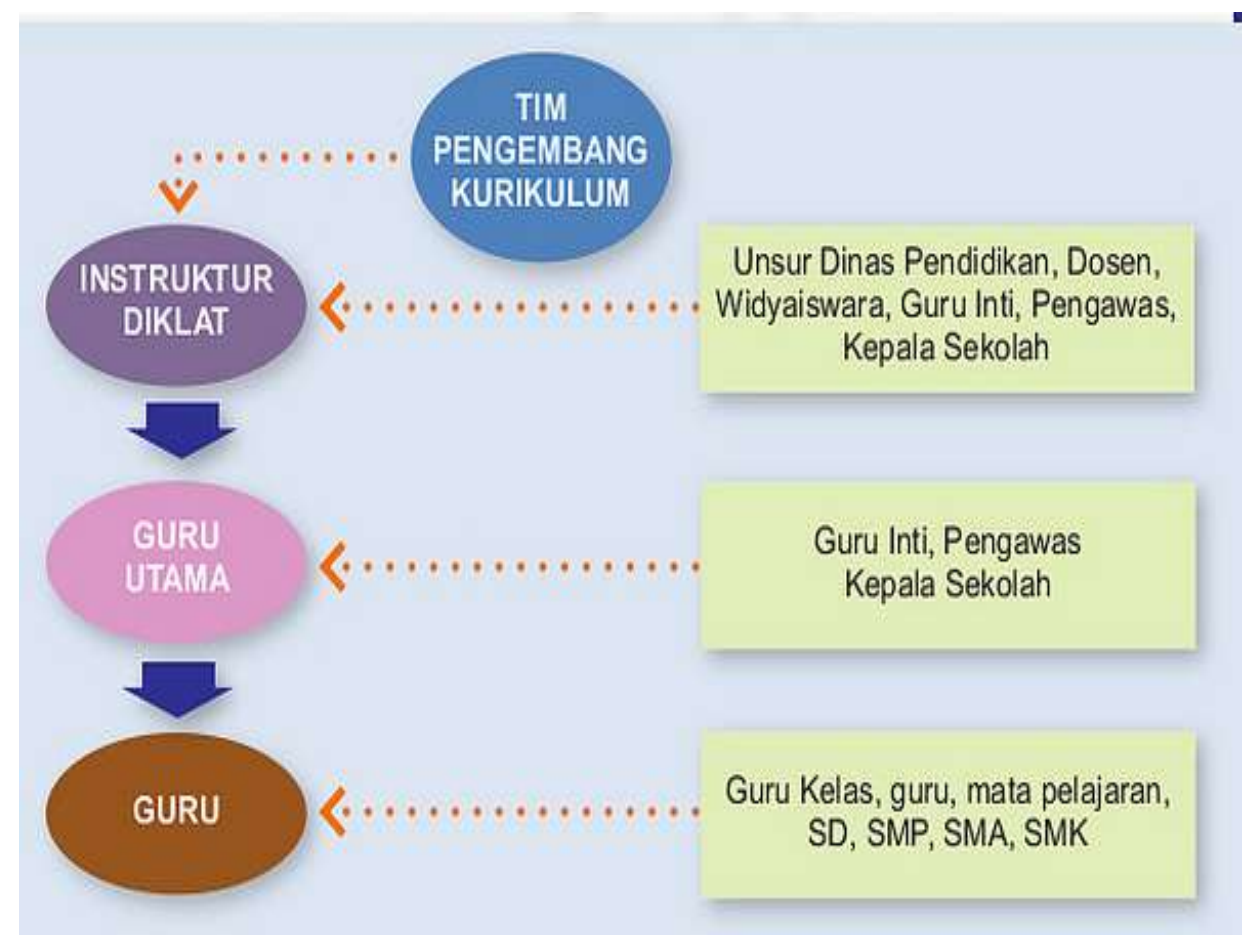

Gambar 3 Skema strategi penyiapan guru

Sumber:http://kemdikbud.go.id

Pada diri guru, sedikitnya ada empat aspek yang harus diberi perhatian khusus dalam rencana implementasi dan keterlaksanaan kurikulum 2013, yaitu kompetensi pedagogi; kompetensi akademik (keilmuan); kompetensi sosial; dan kompetensi manajerial atau kepemimpinan. Guru sebagai ujung tombak penerapan kurikulum, diharapkan bisa menyiapkan dan membuka diri terhadap beberapa kemungkinan terjadinya perubahan.

Kesiapan guru lebih penting daripada pengembangan kurikulum 2013. Kurikulum 2013 bertujuan mendorong peserta didik, mampu lebih baik dalam melakukan observasi, bertanya, bernalar, dan mengkomunikasikan terhadap apa yang mereka peroleh atau mereka ketahui setelah menerima materi pembelajaran 


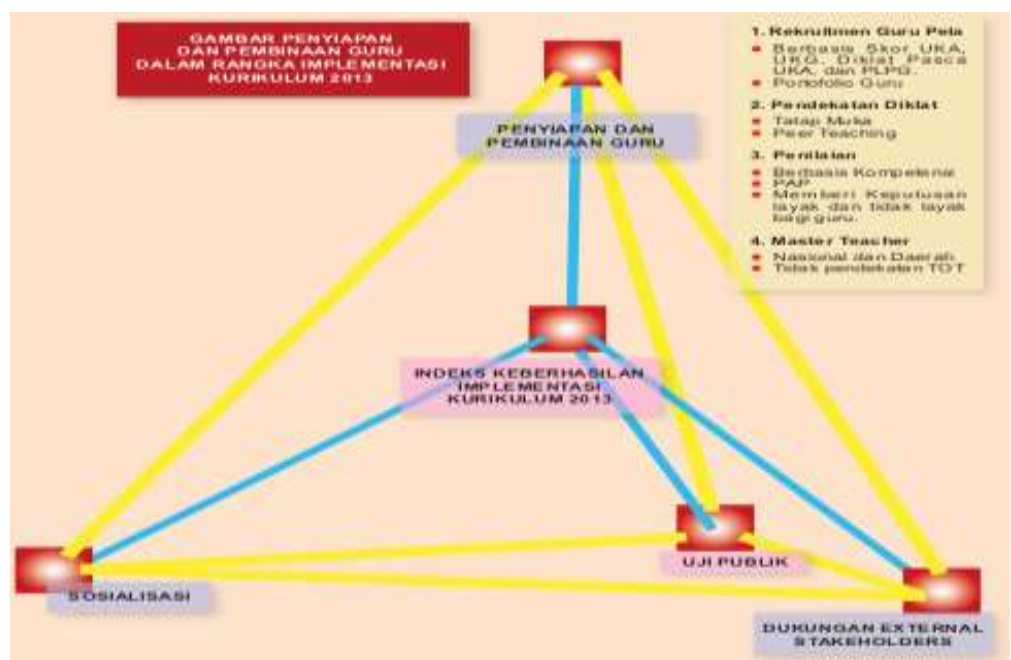

Gambar 4 Skema Penyiapan dan Pembinaan Guru dalam Implementasi Kurikulum 2013

Sumber: http://kemdikbud.go.id,

Dengan buku teks yang baik, yang isinya mencakup semua standar kompetensi (SK) dan kompetensi dasar (KD) sesuai tuntutan standar isi, penyajiannya menarik, bahasanya baku, dan ilustrasinya menarik dan tepat, maka diharapkan proses belajar pembelajaran yang dilakukan guru dan siswa bisa optimal mencapai standar kompetensi lulusan (SKL). Berikut adalah dasar yuridis standar penilaian buku teks pelajaran:

1. PP No. 19/2005 pasal 43 ayat (5): "Kelayakan isi, bahasa, penyajian, dan kegrafikaan buku teks pelajaran dinilai oleh BSNP dan ditetapkan dengan Peraturan Menteri."

2. Permendiknas Nomor 2 Tahun 2008 tentang Buku, Pasal 1:" buku teks adalah buku acuan wajib untuk digunakan di satuan pendidikan dasar dan menengah atau perguruan tinggi yang memuat materi pembelajaran dalam rangka peningkatan keimanan, ketakwaan, akhlak mulia, dan kepribadian, penguasaan ilmu pengetahuan dan teknologi, peningkatan kepekaan dan kemampuan estetis, peningkatan kemampuan kinestetis dan kesehatan yang disusun berdasarkan standar nasional pendidikan. Pasal 4 ayat (1): "Buku teks pada jenjang pendidikan dasar dan menengah dinilai kelayakanpakainya terlebih dahulu oleh Badan Standar Nasional Pendidikan sebelum digunakan oleh pendidik dan/atau peserta didik sebagai sumber belajar di satuan pendidikan". Pasal 10 ayat (1): "satuan pendidikan dasar dan menengah menetapkan masa pakai buku teks sebagaimana dimaksud dalam 
Pasal 5 sesingkat-singkatnya 5 tahun".

Kelayakan Isi, Buku teks pelajaran yang baik seharusnya berisi materi yang mendukung tercapainya SK (standar kompetensi) dan KD (kompetensi dasar) dari mata pelajaran tersebut. Kelayakan isi buku teks pelajaran dapat dinilai dari: Materi berorientasi pada aktivitas yang mendorong pemahaman konsep, Keakuratan materi terjaga, Kemutakhiran dan aktualitas contoh materi, Materi mendorong keingintahuan, dan Materi buku tidak mempertentangkan SARA, tidak bernuansa pornografi, mengakomodasi keberagaman, dan berwawasan gender.

Kelayakan Penyajian, Kelayakan penyajian buku teks pelajaran dapat dinilai dari: Mendorong keterlibatan siswa untuk belajar aktif, Keterkaitan antarbab, antarsubbab, dan antarkonsep,

Keterpaduan/keselarasan

antarkonsep, dan Materi disajikan secara kontekstual

Kelayakan Bahasa, Kelayakan bahasa buku teks pelajaran dapat dinilai dari (1) kesesuaian bahasa dengan perkembangan siswa dan (2) ketepatan penggunaan simbol, istilah, dan/atau ikon.

\section{Kelayakan Kegrafikaan,}

Kelayakan kegrafikaan buku teks pelajaran dapat dinilai dari (1) tata letak unsur grafika estetis, dinamis, dan menarik serta menggunakan ilustrasi yang memperjelas pemahaman materi buku, (2) tipografi yang digunakan mempunyai tingkat keterbacaan yang tinggi, and (3) ilustrasi dan tata letak mempermudah pemahaman materi.

\section{METODE PENELITIAN}

Penelitian ini merupakan penelitian kualitatif-deskriptif. Fokusnya adalah penggambaran secara menyeluruh tentang hasil penelaahan para penelaah independen terhadap buku teks pelajaran kurikulum 2013, dilihat dari empat aspek kelayakan, yang meliputi isi, penyajian, bahasa, dan kegrafikaan. Hal ini sejalan dengan pendapat Sugiyono yang mengatakan bahwa metode kualitatif digunakan untuk mendapatkan data yang mendalam, suatu data yang mengandung makna. Makna adalah data yang sebenarnya, data yang pasti yang merupakan suatu nilai di balik data yang tampak.

Ciri-ciri penelitian kualitatif adalah bersifat eksploratif, teori lahir dan dikembangkan di lapangan, proses berulang-ulang, pembahasan lebih bersifat kasus dan spesifik, dan mengandalkan kecermatan dalam pengumpulan data untuk mengungkap secara tepat keadaan di lapangan yang sesungguhnya. Berdasarkan ciri-ciri tersebut, teknik yang digunakan untuk pengumpulan data kualitatif adalah dengan wawancara mendalam, observasi partisipan, focus group discussion, dan analisis dokumen, sedang instrumen yang digunakan adalah 
kuesioner terbuka dan/atau pedoman wawancara yang tidak terstruktur.

Wawancara Mendalam yaitu teknik wawancara yang didasarkan oleh rasa skeptis yang tinggi, sehingga wawancara ini banyak diwarnai dengan probling. Prakondisi dari wawancara mendalam adalah kedekatan atau keakraban hubungan antara pewawancara dengan yang diwawancarai (responden) serta tingkat pemahaman pewawancara terhadap keinginan, persepsi, prinsip, dan budaya responden. Wawancara dalam penelitian ini dilakukan dengan pihak-pihak terkait yang mengetahui masalah-masalah pokok yang berkaitan dengan masalah penelitian. Mereka adalah Tim Penelaah Independen, Kepala Bidang Kurikulum dan Perbukuan Pendidikan Dasar Puskurbuk selaku ketua pelaksana kegiatan (Erry Utomo), dan Kepala Puskurbuk Balitbang Kemdikbud (Ramon Mohandas).

Observasi Partisipan yaitu suatu bentuk observasi yang menyentuh pada kehidupan atau pekerjaan atau aktivitas subjek yang diobservasi (responden). Di sini, peneliti harus beradaptasi dengan responden. Observasi yang telah dilakukan oleh peneliti dilakukan sejak bulan Januari-Mei, di mana peneliti tergabung dalam Tim Editorial Buku Teks Pelajaran Kurikulum 2013. Keterlibatan langsung ini tidak mempengaruhi subjektivitas peneliti karena pada dasarnya fokus utama dari penelitian ini adalah hasil studi dokumen penelaahan buku teks pelajaran yang telah dilakukan oleh Tim Penelaah Independen Kemdikbud. Fungsi observasi ini untuk mendukung kebutuhan analisis data.

Diskusi Lengkap Terarah (Focus Group Discussion). Menurut Effi Aswita Lubis, diskusi lengkap terarah bertujuan untuk menggali dan mengidentifikasi pola, tingkah laku, opini, sikap, dan motivasi, yang relevan dengan tujuan penelitian. Teknisnya adalah dengan mengelompokkan responden yang mempunyai ciri-ciri yang sejenis (homogen) kemudian diajak diskusi dipandu seorang anggota peneliti sebagai moderator. Bahan diskusi yang terkait dengan masalah yang diangkat dalam penelitian ini adalah bagaimana pendapat para responden terhadap kelayakan isi, penyajian, bahasa, dan kegrafikaan buku teks pelajaran yang mereka telah telaah.

Telaah Dokumen yaitu teknik pengumpulan data yang dilakukan dengan menelaah dokumen yang ada untuk mempelajari pengetahuan dan fakta yang hendak diteliti. Telaah dokumen dalam penelitian ini merupakan teknik utama yang digunakan oleh peneliti dalam menghimpun data penelitian. Kepala Bidang Kurikulum dan Perbukuan Pendidikan Dasar, Puskurbuk, Erry Utomo selaku ketua pelaksana penyusunan buku teks pelajaran kurikulum 2013 mengatakan, buku yang selesai disusun juga harus mendapat persetujuan dari Badan Standar Nasional Pendidikan 
(BSNP). Penilaian dilakukan agar BSNP dapat melihat apakah masih ada kekurangan yang perlu ditambahkan dalam buku Kurikulum 2013 tersebut.

Analisis dalam penelitian ini sangat bergantung pada kemampuan peneliti, artinya analisis tersebut tidak mengandalkan rumus baku tetapi lebih mengandalkan kepada kemampuan kedalaman dan keleluasaan peneliti.

\section{Organisasi Data}

Data dalam penelitian ini banyak sekali. Data tersebut perlu dibaca dan dibaca kembali agar peneliti dapat memahami data tersebut. Selama membaca, peneliti membuat catatan dan mengeditnya bila perlu. Catatan ini penting untuk menyusun dan menganalisis data. Data penelitian ini terdiri dari satu paket hasil wawancara, satu paket hasil observasi, dan satu paket hasil telaah dokumen. Dalam hal ini, peneliti menggunakan nama-nama buku sebagai satuan data, sehingga data yang terkumpul adalah 76 data buku.

\section{Kategorisasi, Tema, dan Pola}

Tahapan ini merupakan tahapan yang paling sulit sekaligus juga menuntut kreativitas berpikir peneliti. Dari 76 data buku yang telah disusun, peneliti memilahkannya berdasarkan jenjang pendidikan, sesuai data yang tercantum pada Permendikbud No 71 Tahun 2013, pemerintah telah menetapkan dan menerbitkan 76 Buku Teks Pelajaran Kurikulum
2013, dengan rincian 16 buku teks pelajaran Tematik SD/MI Kelas I dan IV; 18 buku teks pelajaran Mata Pelajaran SMP/MTs Kelas VII; 6 buku teks pelajaran Mata Pelajaran SMA/MTs Kelas X; dan 36 buku teks pelajaran Agama SD I, IV, dan SMP VII.

\section{Validasi Data}

Tahapan ini mencakup upaya mengevaluasi data untuk melihat kelayakan, kredibilitas, kemanfaatan, dan pemusatan informasi. Data utama yang digunakan peneliti dalam penelitian ini adalah instrumen penelaahan yang telah diisi oleh para penelaah buku teks pelajaran kurikulum 2013. Data ini dinilai valid karena telah disiapkan oleh Tim BSNP yang dalam kegiatan penyusunan buku teks pelajaran ini mereka tergabung dalam Tim Reviewer Independen yang ditetapkan oleh Mendikbud. Sedangkan hasil wawancara dan observasi digunakan untuk mendukung data utama yang ada.

\section{Analisis Data}

Analisis data dilakukan dengan tiga tahapan, yaitu reduksi data, sajian data, dan penarikan simpulan/verifikasi.

\section{Reduksi Data}

Reduksi data adalah bagian dari proses yaitu bentuk analisis untuk mempertegas, memperpendek, membuat fokus, membuang hal yang tidak penting, untuk mengatur data sehingga data ditarik kesimpulan. Ke-76 paket data, direduksi menjadi 18 paket data yang ditetapkan atas 
dasar keterwakilan dari setiap jenjang pendidikan, baik SD, SMP, maupun SMA dan atas latar belakang pendidikan dan agama peneliti (khusus data buku agama). Berikut detail rinciannya: Diriku dan Kegemaranku Tematik Kelas I SD; Indahnya Kebersamaan dan Selalu Berhemat Energi Tematik Kelas IV SD; Bahasa Indonesia, Bahasa Inggris, Pendidikan Pancasila dan Kewarganegaan, Ilmu Pengetahuan Sosial, Prakarya, dan Seni Budaya Kelas VII SMP; Bahasa Indonesia dan Sejarah Kelas X SMA; Pendidikan Agama Kristen dan Budi Pekerti Kelas I SD, IV SD, VII SMP; dan Pendidikan Agama Katolik dan Budi Pekerti Kelas I SD, IV SD, dan VII SMP

\section{Sajian Data}

Sajian data adalah suatu susunan informasi yang memungkinkan dapat ditariknya suatu kesimpulan penelitian. Dengan melihat sajian dapat, peneliti akan memahami apa yang terjadi serta memberikan peluang bagi peneliti untuk mengerjakan sesuatu pada analisis atau tindakan lain berdasarkan pemahamannya. Dalam penelitian ini, data disajikan dengan bar-chart yang memuat skor penilaian buku oleh penelaah terhadap unsur kelayakan isi, penyajian, bahasa, dan kegrafikaan buku tertentu. Bar-chart ini sangat berguna untuk mendapatkan gambaran yang jelas dan memudahkan dalam menyusun kesimpulan penelitian.

\section{Penarikan Simpulan/Verifikasi}

Kesimpulan akhir pada penelitian kualitatif, tidak akan ditarik kecuali setelah proses pengumpulan data berakhir. Kesimpulan yang dibuat perlu diverifikasi dengan cara melihat dan mempertanyakan kembali, sambil meninjau secara sepintas pada catatan lapangan untuk memperoleh pemahaman yang tepat.

\section{HASIL DAN PEMBAHASAN}

Dalam Permendikbud No 71 Tahun 2013, pemerintah telah menetapkan dan menerbitkan 76 Buku Teks Pelajaran Kurikulum 2013, dengan rincian sebagai berikut.

a. 16 buku teks pelajaran Tematik SD/MI Kelas I dan IV

b. 18 buku teks pelajaran Mata Pelajaran SMP/MTs Kelas VII

c. 6 buku teks pelajaran Mata Pelajaran SMA/MTs Kelas X

d. 36 buku teks pelajaran Agama SD I, IV, dan SMP VII.

Untuk mendapatkan deskripsi data yang rinci, peneliti mereduksi data dan menetapkan 18 buku teks pelajaran sekolah untuk dijadikan data penelitian ini (sebanyak $23,68 \%$ ).

Pada bagian analisis data ini, peneliti memperbandingkan hasil penelaahan 18 buku yang dijadikan data dalam penelitian ini. Hasil perbandingan menunjukkan peringkat kelayakan buku dilihat dari segi isi, penyajian, bahasa, dan kegrafikaan. 


\section{Kelayakan Isi}

Tabel 1 Rata-Rata Skor Kelayakan Isi

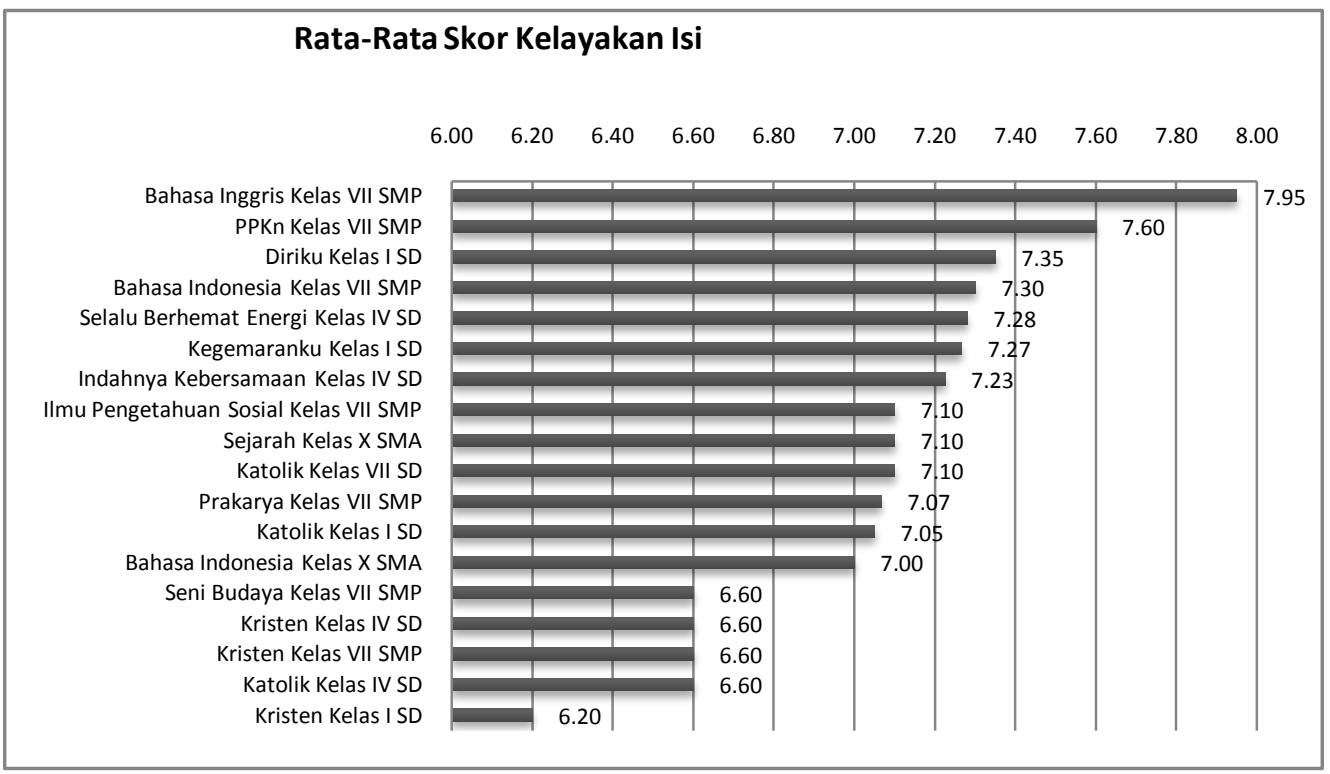

Tabel 1 merupakan rekapitulasi rata-rata skor kelayakan isi buku teks pelajaran yang mendukung penerapan kurikulum 2013. Ditinjau dari segi kelayakan isi, berdasarkan tabel di atas 5 buku masuk kategori 'cukup layak' (skor 6,00 - 6,99) dan 13 buku termasuk kategori 'layak' (skor 7,00-7,99). Buku yang masuk kategori 'cukup layak' adalah Seni Budaya Kelas VII SMP, Pend. Agama Katolik Kelas IV SD, dan Pend. Agama Kristen Kelas I, IV, dan VII. Adapun ke-13 buku yang dinyatakan memenuhi unsur kelayakan adalah 4 buku tematik SD, 5 buku SMP Kelas VII (Bahasa Indonesia, Bahasa Inggris, PPKn, IPS, dan Prakarya), 2 buku SMA Kelas X (Bahasa Indonesia dan Sejarah Indonesia), dan 2 buku agama (Pend. Agama Katolik Kelas I dan VII).

\section{Kelayakan Penyajian}

Tabel 2 merupakan rekapitulasi rata-rata skor kelayakan penyajian buku teks pelajaran kurikulum 2013. Ditinjau dari segi kelayakan penyajian, berdasarkan Tabel 2, ada 6 buku masuk kategori 'cukup layak' (skor 6,00 - 6,99) dan 12 buku termasuk kategori 'layak' (skor 7,00 $-7,99)$.

Rata-rata skor kelayakan penyajian buku teks pelajaran kurikulum 2013. Ditinjau dari segi kelayakan penyajian, berdasarkan Tabel 4.20, ada 6 buku masuk kategori 'cukup layak' (skor 6,00 6,99) dan 12 buku termasuk kategori 'layak' (skor 7,00-7,99). 
Tabel 2 Rata-Rata Skor Kelayakan Penyajian

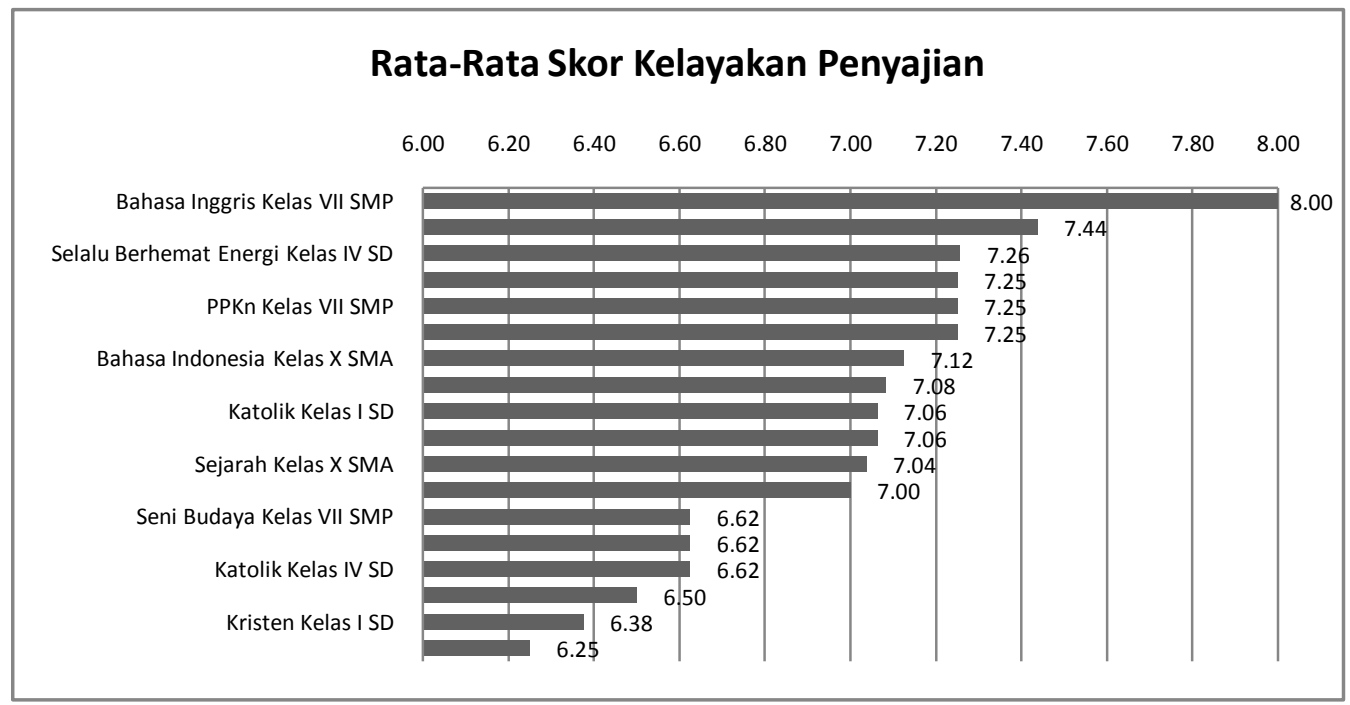

Buku yang masuk kategori 'cukup layak' adalah Seni Budaya dan Prakarya Kelas VII SMP, Pendidikan Agama Katolik Kelas IV $\mathrm{SD}$, dan Pendidikan Agama Kristen Kelas I, IV, dan VII. Adapun ke-12 buku yang dinyatakan memenuhi unsur kelayakan adalah 4 buku tematik SD (Diriku, Kegemaranku,
Indahnya Kebersamaan, dan Selalu Berhemat Energi), 4 buku SMP Kelas VII (Bahasa Indonesia, Bahasa Inggris, PPKn, dan Ilmu Pengetahuan Sosial), 2 buku SMA Kelas X (Bahasa Indonesia dan Sejarah Indonesia), dan 2 buku agama (Pendidikan Agama Katolik dan Budi Pekerti Kelas I dan VII).

\section{Kelayakan Bahasa}

Tabel 3 Rata-Rata Skor Kelayakan Bahasa

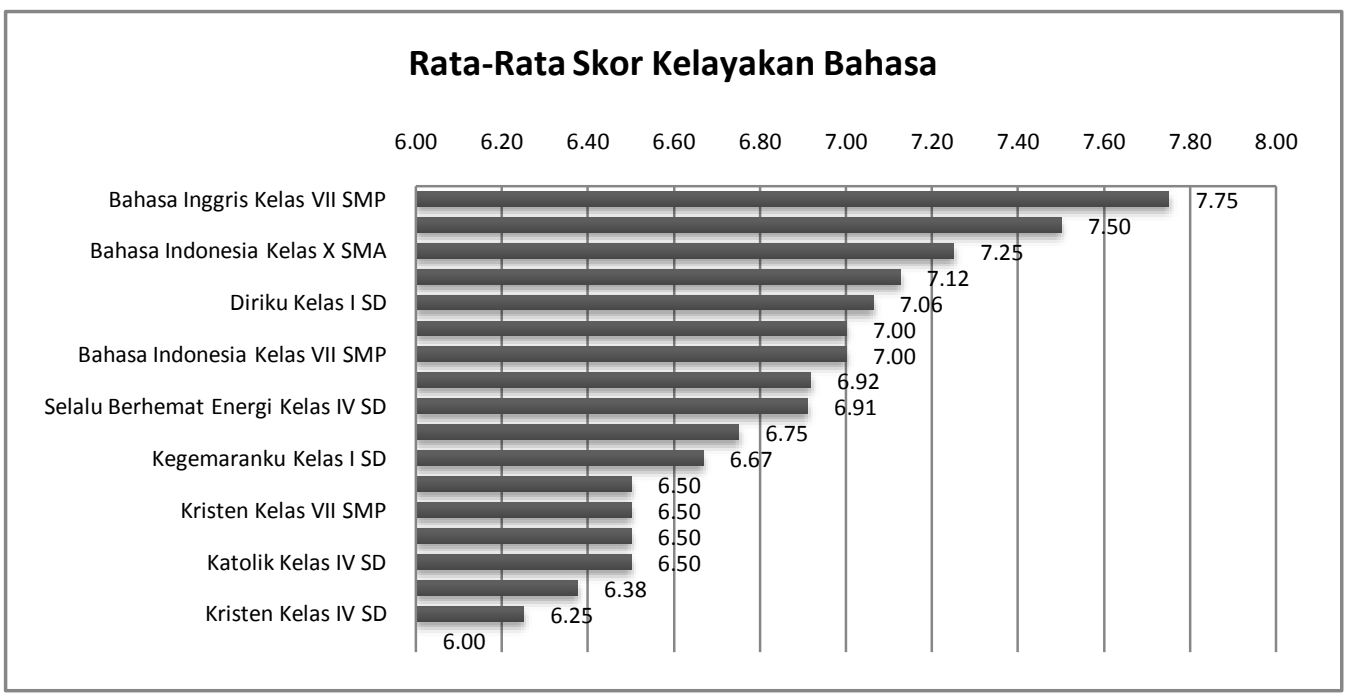


Tabel 3 merupakan rekapitulasi rata-rata skor kelayakan bahasa yang digunakan dalam buku teks pelajaran kurikulum 2013. Ditinjau dari segi kelayakan bahasa, berdasarkan Tabel 4.21, ada 11 buku masuk kategori 'cukup layak' (skor 6,00-6,99) dan 7 buku termasuk kategori 'layak' (skor 7,00-7,99).

Buku yang masuk kategori 'cukup layak' unsur bahasanya adalah tiga buku Pendidikan Agama Kristen, tiga buku Pendidikan Agama Katolik Kelas I, IV, dan VII, Seni Budaya VII, Prakarya Kelas VII, 2 buku tematik (Kegemaranku dan Selalu Berhemat Energi) serta Sejarah Indonesia X. Adapun ketujuh buku yang dinyatakan memenuhi unsur kelayakan adalah Diriku I, Indahnya Kebersamaan IV, Bahasa Indonesia VII, Bahasa Inggris VII, PPKn VII, Ilmu Pengetahuan Sosial VII, dan Bahasa Indonesia $X$.

\section{Kelayakan Kegrafikaan}

Tabel 4 merupakan rekapitulasi rata-rata skor kelayakan kegrafikaan buku teks pelajaran kurikulum 2013. Ditinjau dari segi kelayakan kegrafikaan, berdasarkan Tabel 4.22, ada 10 buku masuk kategori 'cukup layak' (skor 6,00 - 6,99) dan 8 buku termasuk kategori 'layak' (skor 7,00 $-7,99)$.

Tabel 4 Rata-Rata Skor Kelayakan Kegrafikaan

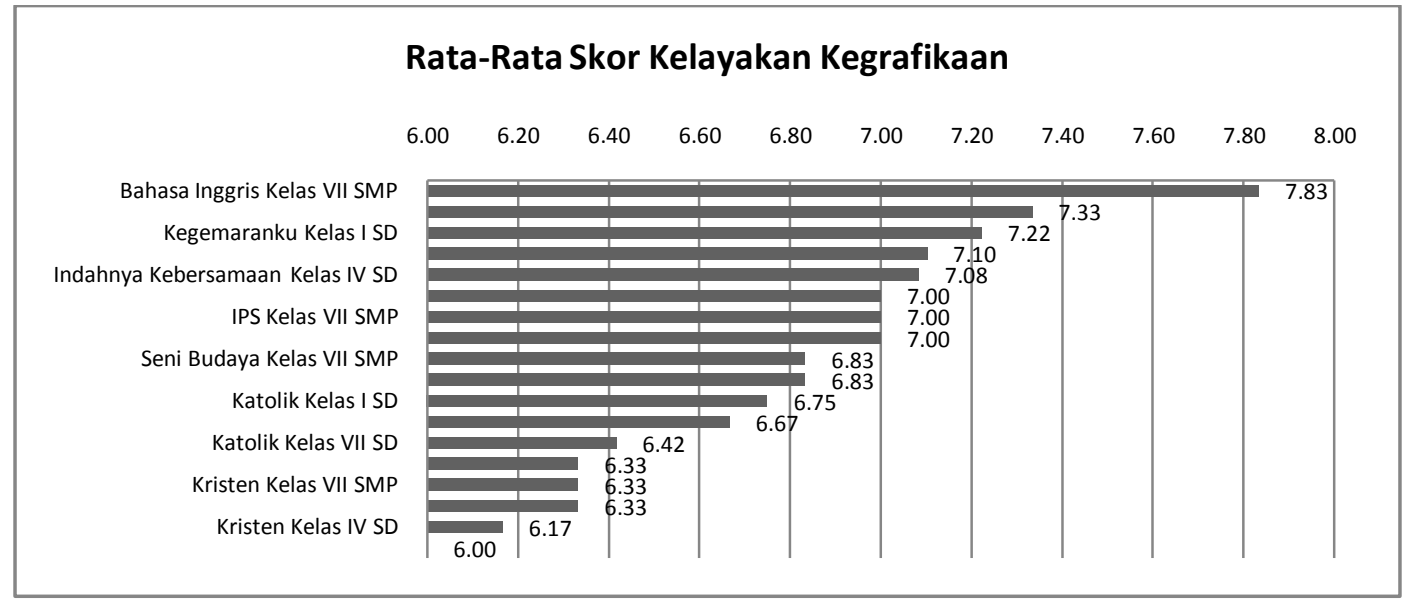

Buku yang masuk kategori 'cukup layak' unsur bahasanya adalah 3 Pendidikan Agama Kristen, 3 buku Pendidikan Agama Katolik (Kelas I, IV, dan VII), Seni Budaya VII, Prakarya Kelas VII, Bahasa Indonesia VII dan X. Adapun delapan buku lainnya memenuhi unsur kelayakan adalah empat buku tematik, Bahasa Inggris VII, PPKn VII, Ilmu Pengetahuan Sosial VII.

Peneliti mendapatkan gambaran hasil penelaahan buku teks pelajaran kurikulum 2013 ditinjau dari aspek kelayakan isi, penyajian, bahasa, dan kegrafikaan. Berikut adalah perbandingan skor rata-rata kelayakan buku teks pelajaran tersebut. 
Tabel 5 Rata-Rata Skor Kelayakan Buku

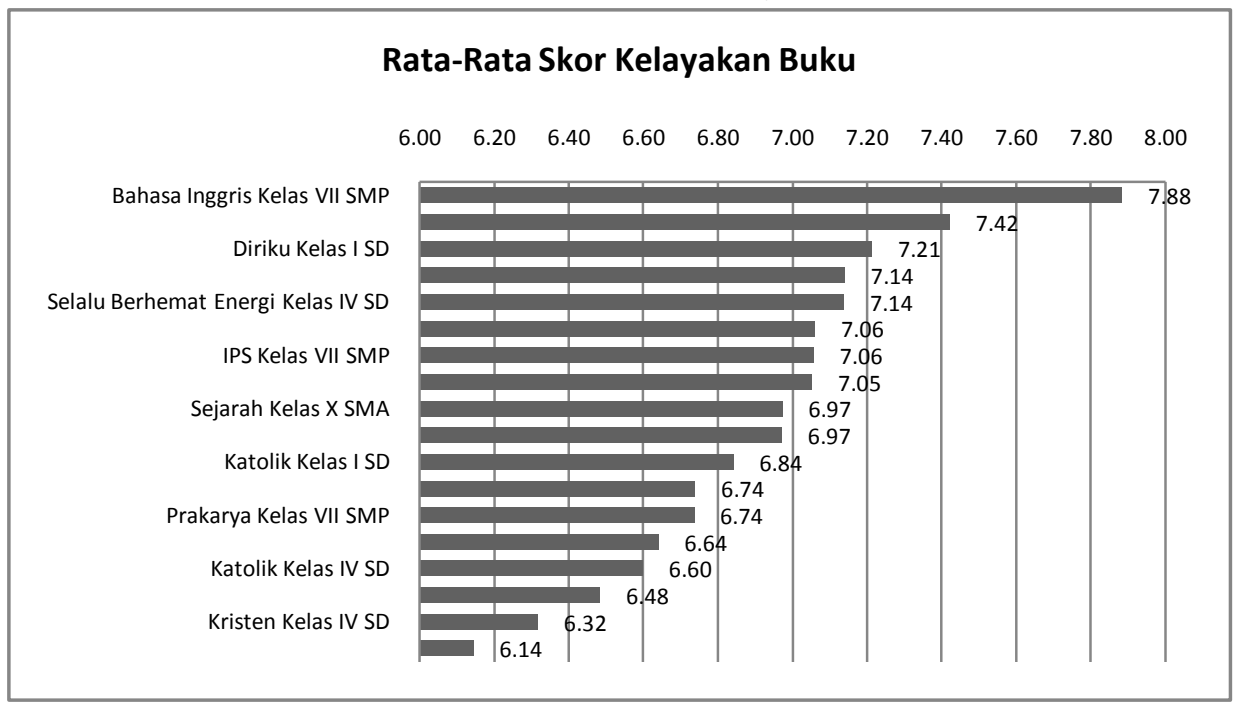

Pada Tabel 5 dapat dilihat bahwa buku yang mendapatkan penilaian tiga tertinggi adalah (1) Bahasa Inggris, (2) PPKn, dan (3) Diriku. Sebaliknya, tiga buku dengan penilaian terendah adalah Pendidikan Agama Kristen dan Budi Pekerti Kelas I, IV, dan VII.

Secara keseluruhan, aspek kelayakan buku teks pelajaran kurikulum 2013 ini terbagi menjadi dua kategori, yaitu 'cukup layak' dan 'layak'. Adapun buku yang termasuk kategori 'cukup layak' ada sepuluh buku dan delapan buku sisanya telah memenuhi unsur kelayakan suatu buku teks pelajaran.

Pada prinsipnya, materi isi kedelapan belas buku yang telah dijabarkan satu per satu di atas telah memenuhi unsur kelayakan isi. Hal ini didukung dengan kesepakatan para penelaah bahwa materi sudah berorientasi pada aktivitas yang dapat mendukung proses pembelajaran. Keakuratan materi juga dinilai sudah sesuai dengan KD dan indikator yang dirumuskan. Kemuktahiran dan aktualitas juga cukup memadai. Materi dinilai sudah mendorong rasa ingin tahu siswa untuk memahami sesuatu. Materi buku juga tidak mempertentangkan SARA dan tidak bernuansa pornografi. Buku juga dinilai mengakomodasi keberagaman dan berwawasan gender. Namun demikian, setiap buku tersebut masih memiliki kelemahan/catatan revisi dari para penelaah. Jika catatan tersebut dapat dipertimbangkan dan diperbaiki, materi isi buku akan makin lebih baik.

Terkait dengan kelayakan penyajian, buku teks kurikulum 2013 dinilai cukup mampu mendorong keterlibatan siswa untuk belajar aktif bertanya, menjelaskan, mengamati, mencoba, dan melakukan.Perbaikan perlu dilakukan dengan melengkapi penyajian latihan yang memupuk keterampilan bertanya siswa. 
Keterkaitan antarbab, antarsubbab, dan antarkonsep dinilai sudah sesuai kriteria walaupun masih ada bagianbagian yang perlu diperbaiki. Penyajian dinilai sudah mempunyai keterkaitan antarbab, antarsubbab, dan antarkonsep. keselarasan antarkonsep sudah memenuhi kriteria dan cukup selaras. Perbaikan perlu dilakukan pada keterkaitanantara contoh dan konsep saja. Materi juga sudah disajikan sesuai kriteria secara kontekstual.

Terhadap kelayakan bahasa, penelaah berpendapat bahwa secara umum bahasa yang digunakan sudah sesuai dengan perkembangan siswa. Ada buku malah masuk kategori sangat layak unsur kebahasaannya, yaitu Bahasa Inggris Kelas VII. Namun demikian, hampir di semua buku masih perlu perbaikan, khususnya di buku-buku untuk jenjang SD, perlu penyederhanaan kalimat yang panjang dengan tidak mengubah maksud kalimat. Perlu penyederhanaan pertanyaan yang terlalu panjang, penambahan contoh, dan pembuatan perintah yang jelas sesuai denganmateri yang disajikan. Juga perlu menyesuaikan kata yang diawali dengan huruf kapital, khususnya nama orang. Namun demikian secara keseluruhan bahasa yang digunakan dalam penyampaian materi cukup komunikatif hingga memudahkan siswa untuk memahami pembelajaran. Mengenai ketepatan penggunaan istilah, simbol, dan kata atau ikon sudah sesuai kriteria, tetapi masih ada penggunaan EYD yang perlu diperbaiki. Istilah yang digunakan dalam buku ini sudah cukup tepat. Namun sebagian masih terdapat catatan perbaikan dan penyesuaian kalimat agar bahasanya lebih komunikatif.

\section{PENUTUP}

Dengan penelitian kualitatif pada akhirnya, peneliti menyimpulkan penelaahan buku teks pelajaran kurikulum 2013.

a. Aspek kelayakan isi,

Ditinjau dari segi kelayakan isi, dari 18 buku yang dijadikan sampel penelitian, ada 5 (lima) buku yang termasuk kategori 'cukup layak' (skor 6,00-6,99) dan 13 (tigabelas) buku termasuk kategori 'layak' (skor 7,00-7,99). Artinya, para penelaah menyatakan dilihat dari segi kelayakan ini, sebagian besar buku teks pelajaran kurikulum 2013 'layak' untuk diterbitkan.

b. Aspek Kelayakan Penyajian

Ditinjau dari segi kelayakan penyajian, ada 6 (enam) buku masuk kategori 'cukup layak' (skor 6,00-6,99) dan 12 (duabelas) buku termasuk kategori 'layak' (skor 7,00-7,99). Artinya, sependapat dengan hasil penelaahan kelayakan isi, para penelaah menyatakan bahwa sebagian besar penyajian buku teks pelajaran kurikulum 2013 sudah memadai dan 'layak' untuk diterbitkan.

c. Aspek Kelayakan Bahasa

Ditinjau dari segi kelayakan bahasa, ada 11 (sebelas) buku 
masuk kategori 'cukup layak' (skor 6,00-6,99) dan 7 (tujuh) buku termasuk kategori 'layak' (skor 7,00-7,99). Buku yang masuk kategori 'cukup layak' unsur bahasanya adalah tiga buku Artinya, berbeda dengan hasil penelaahan aspek isi dan penyajian, para penelaah menyatakan bahwa sebagian besar buku teks pelajaran kurikulum 2013 hanya cukup memadai untuk digunakan sebagai buku acuan siswa.

d. Aspek Kelayakan Kegrafikaan

Ditinjau dari segi kelayakan kegrafikaan, ada 10 (sepuluh) buku masuk kategori 'cukup layak' (skor 6,00-6,99) dan 8 (delapan) buku termasuk kategori 'layak' (skor 7,00-7,99). Artinya, para penelaah menyatakan bahwa sebagian buku teks pelajaran kurikulum 2013 hanya cukup memadai untuk digunakan sebagai buku acuan siswa. Jika tetap akan digunakan sebagai buku acuan siswa, tim penulis dan tim desain buku harus memperbaiki unsur kegrafikaan ini.

Secara keseluruhan, aspek kelayakan buku teks pelajaran kurikulum 2013 ini terbagi menjadi dua kategori, yaitu 'cukup layak' dan 'layak'. Adapun buku yang termasuk kategori 'cukup layak' ada sepuluh buku dan delapan buku sisanya telah memenuhi unsur kelayakan suatu buku teks pelajaran. Artinya bukubuku yang telah diteliti kelayakannya ini telah memenuhi kriteria minimal buku ajar yang digunakan dalam penerapan kurikulum 2013. Namun demikian, untuk menjadikannya buku teks pelajaran yang digunakan secara nasional, aspek isi, penyajian, bahasa, dan kegrafikaan buku tersebut harus diperbaiki, dilengkapi, dan dimaksimalkan lagi.

\section{DAFTAR RUJUKAN}

Effi Aswita Lubis. 2012. Metode Penelitian Pendidikan. Medan: UNIMED PRESS

Panduan Penilaian Buku Teks Pelajaran Badan Standar Nasional Pendidikan

Robert C. Bogdan dan Stevcen, J. Taylor, 1992, Introduction to Qualitative reasearch methods: a phenomenological approach in the social sciences, alih bahasa Arif Furchan, John wiley and son, Surabaya: Usaha Nasional

Sugiyono, 2009, Metode Penelitian Administrasi, Bandung: Alfa Beta

http://www.artikata.com/arti380917-penelaahan.html, diakses 1009-2013, 09.35

http://www.belajar.kemdikbud.go.id http://kemdikbud.go.id, diakses 12 September 2013, 10:02 http://www.puskurbuk.go.id 